\title{
NINE JUSTICES IN SEARCH OF A DOCTRINE
}

\author{
Thomas I. Emerson*
}

$\mathrm{T}$ HE case of Griswold $v$. Connecticut, ${ }^{1}$ like few others in recent times, presented the United States Supreme Court with a hopelessly unsupportable piece of state legislation and an unusual variety of possible doctrinal solutions. The Court's response to this situation, and the implications of its choice of doctrine for the future of individual rights in America, make an intriguing study of the judicial process.

The Connecticut law, as a matter of social policy, had little or nothing to be said for it. It was enacted in 1879 and remained as a relic of a Comstockian philosophy which had long since ceased to be widely held, if it ever had been. The statute was at war with all accepted standards of medical practice. It invaded the sacred realm of marital privacy, and for all practical purposes denied to married couples the right of deciding whether or when to have children. Under certain not infrequent circumstances, it imposed upon individuals the cruel choice between sexual abstinence on the one hand and ill health, death, or deformed children on the other. Not generally enforced, indeed unenforceable in most instances, it hung like a cloud over the medical profession. More important, its enforcement only against birth control clinics resulted in patent discrimination against persons who were too poor or too uneducated to seek private medical advice. Its basic purpose was fantastically in conflict with the clearly perceived need to deal with the world's second most critical problem-the population explosion. Even its staunchest supporter, the Roman Catholic Church, was ready to concede that the use of contraceptives by married couples involved a religious principle rather than a public policy to be imposed on all faiths by government sanction. Yet the legislature failed to repeal the statute. ${ }^{2}$

To the ordinary layman, Griswold v. Connecticut seemed easy. But to the lawyer it was somewhat more difficult. The lawyer's problem with the case was that the issues did not readily fit into

- Professor of Law, Yale University.-Ed. The author wishes to point out that he was one of the counsel for appellants in the case of Griswold v. Connecticut. This article is written in the capacity of law professor rather than advocate, but the bias should be noted.

1. 381 U.S. 479 (1965).

2. There is some evidence that, at least when the case was in its final stages before the Supreme Court, many Connecticut legislators preferred to have the Court, rather than themselves, make the decision to eliminate the statute.

[219] 
any existing legal pigeonhole. Actually, there were five possibilities. The case could have been dealt with under the equal protection clause, the first amendment, substantive due process, the right of privacy, or, in extremis, the ninth amendment. In order to strike down the statute under any of these doctrines, however, the Court would be forced to enter uncharted waters. Whatever course the Court took, its action was bound to be pregnant with possibilities crucial to the development of the law in a vital area of American life.

\section{Equal Protection}

The primary equal protection issue arose out of the fact, already mentioned, that although the Connecticut birth control law was a dead letter as far as private physicians and individuals were concerned, it was effectively enforced against birth control clinics. Thus, in actual operation the law did not apply to the private sector of medical practice but did restrict the public sector, thereby discriminating against persons of low income or little education. A subsidiary equal protection issue was that the law, in effect, favored unmarried persons as against married couples. Contraceptives could be legally sold in Connecticut for prevention of disease; faithful partners to a marriage would have no occasion to use them for such purposes, whereas unmarried persons could legally do so. The same factors favored persons engaging in extramarital relations.

Appellants did not rely on the equal protection argument as such, although they did urge it upon the Court as an element of substantive due process. At the very opening of oral argument, however, Mr. Justice Brennan raised the issue, and other Justices indicated their interest in it. Similarly, Mr. Justice White, in his concurring opinion, although proceeding primarily on due process grounds, stressed that "a statute with these effects bears a substantial burden of justification when attacked under the Fourteenth Amendment," citing three equal protection cases. ${ }^{3}$

The problem posed is a far-reaching one. The Court has of course employed the equal protection clause, with increasing refinements and elaboration, in the area of race relations. The important question is how much further the Court will go in utilizing this constitutional provision to aid the economically and socially disadvantaged. The Court is steadily moving in that direction. Already it has insisted upon eliminating some of the effects of gross disparity in

3. 381 U.S. at 503. The equal protection cases cited, along with a due process case, were McLaughlin v. Florida, 379 U.S. 184 (1964); Skinner v. Oklahoma, 316 U.S. 585 (1942); Yick Wo v. Hopkins, 118 U.S. 356 (1886). 
income between defendants caught in the criminal process, ${ }^{4}$ it has invoked the equal protection clause to achieve political equality in reapportionment cases, ${ }^{5}$ and it has relied upon the clause to protect a business enterprise against economic grudge legislation. ${ }^{6}$ As the war against poverty demonstrates, few issues are of more importance to the society of the future than that of assisting its disadvantaged members.

However, the development of equal protection along these lines raises a host of obvious difficulties. It will not be easy to reconcile such equal protection theories with the economic and social laissezfaire assumptions and practices upon which our society has operated over many years and to which it still largely adheres. These uncertainties persuaded counsel for the appellants that there was little to gain in raising bare equal protection issues, as distinct from substantive due process issues, in this litigation. Under the circumstances, the Court, probably wisely, refrained from probing further. However, the interest in the issue evidenced by some members of the Court carries a portent for the future.

\section{The FIRST AMENDMENT}

The first amendment issue was raised by appellants, but it was relatively weak. It was quite evident that appellants had engaged in some conduct-such as giving physical examinations and dispensing contraceptives-which could be classified only as action rather than speech. Their argument conceded this point, but stressed two other factors. First, the aiding and abetting statute, under which appellants were actually convicted, made it a crime not only to "assist" and "abet" another person to commit an offense, but also to "counsel" him to do so. Thus, at least in theory and possible application, this statutory provision swept broadly into the first amendment area. Second, in the conduct of the trial no effort had been made to distinguish between protected areas of speech and unprotected areas of action; everything was mixed together in one grab bag.

The case thus involved two crucial aspects of first amendment theory. One concerns the coverage of the first amendment-the extent to which it protects conduct that is not strictly speech but is essential to the exercise of free speech. The other, closely related, is the problem of separating speech from action in a complex situa-

\footnotetext{
4. See, e.g., Griffin v. Illinois, 351 U.S. 12 (1956).

5. See, e.g., Baker v. Carr, 369 U.S. 186 (1962).

6. See Morey v. Doud, 354 U.S. 457 (1957).
} 
tion, rather than lumping them together in a way which penalizes speech in the course of regulating action. The Court has come more and more to recognize these problems and has begun to deal with them. In view of the multiplying indirect restrictions upon speech, these questions are bound to become key issues in our effort to maintain a system of freedom of expression.

The birth control case, however, did not present a very favorable opportunity for the Court to press forward on these frontiers. The Court would have had to go beyond anything it had decided before, and it would have had to face some hard problems in determining how far to cut down aiding and abetting statutes and, indeed, much legislation dealing with inchoate crimes. Although the Court refrained from treating first amendment problems directly, first amendment overtones were strongly heard in the prevailing opinion of Mr. Justice Douglas. It would seem clear that any state law applied to prohibit the giving of advice on the value or methods of contraception would fall under the ban of the first amendment. More important, while there is nothing in the opinions on the question of separating speech from action, the Douglas opinion does continue the dialogue on the issue of first amendment coverage.

\section{Substantive Due Process}

Substantive due process issues were central to the case. Not only was the direct argument strongly urged, but due process considera. tions were also involved in the right of privacy issue, to be discussed later.

The space available here does not permit a detailed analysis of the Connecticut law or its operation, beyond what has already been undertaken. Suffice it to say that a factual demonstration that the law was arbitrary, unreasonable, capricious, and not reasonably related to a proper legislative purpose, did not pose serious difficulties. This feature of the case was the basis for lay optimism over the outcome. The due process argument was facilitated, moreover, by the fact that neither the Connecticut legislature nor the courts had ever fully articulated, much less defended, the objectives of the legislature in enacting the law. Starting from this point, however, there were two aspects of due process which raised significant ques-

7. With respect to the coverage of the first amendment, see NAACP v. Button, 371 U.S. 415 (1963). With respect to the separation of speech and action, see Gibson $v$. Legislative Investigation Comm., 372 U.S. 539 (1963). For a further discussion of these matters, see Emerson, Freedom of Association and Freedom of Expression, 74 YALE L.J. 1, 24-32 (1964). 
tions. The first was whether the Court would undertake to elaborate a distinction between the application of substantive due process to cases involving personal rights and its application to cases concerning economic rights. The second involved the question as to what standards of due process are to be employed in considering legislation based not on objective facts related to the public welfare, but rather on grounds of purely moral principle.

\section{A. Substantive Due Process and the Distinction Between Personal and Economic Rights}

In the development of substantive due process, attention has been primarily focused upon cases where the doctrine has been invoked in opposition to economic or social welfare legislation. The earlier cases, in which due process was freely employed to strike down such legislation, are typified by Lochner $v$. New York. ${ }^{8}$ However, beginning in the middle thirties with Nebbia v. New York ${ }^{8}$ and West Coast Hotel Co. v. Parrish, ${ }^{10}$ the Court sharply shifted direction, and since that time it has been virtually unwilling to listen to the due process argument in such cases. ${ }^{11}$ At the same time, there has been developing another line of cases in which due process is utilized on behalf of individual or personal rights. This second line of authority commenced with Meyer $v$. Nebrask $a,{ }^{12}$ in which the Court held invalid a state statute prohibiting the teaching of the German language to pupils who had not passed the eighth grade, and Pierce $v$. Society of Sisters, ${ }^{13}$ in which the Court ruled unconstitutional a law preventing the operation of private schools. The Meyer and Pierce decisions, in which Mr. Justice McReynolds wrote for the Court, did not distinguish between personal and economic rights, and the decisions in fact leaned heavily upon the need for protecting property rights. Nevertheless, the distinction is implicit.

More recently, the Court has expressly employed the due process doctrine to uphold individual rights in a variety of cases. One example of this approach is Wieman $v$. Updegraff, ${ }^{14}$ in which a state loyalty program that penalized innocent membership in a "sub-

8. 198 U.S. 45 (1905).

9. 291 U.S. 502 (1934).

10. 300 U.S. 379 (1937).

11. See, e.g., Ferguson v. Skrupa, 372 U.S. 726 (1963); Williamson v. Lee Optical Co,, 348 U.S. 483 (1955); Berman v. Parker, 348 U.S. 26 (1954); Lincoln Fed. Labor Union v. Northwestern Iron \& Metal Co., 335 U.S. 525 (1949).

12. 262 U.S. 390 (1923).

13. 268 U.S. 510 (1925).

14. 344 U.S. 183 (1952).

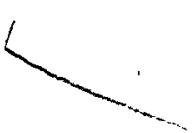


versive" organization was found to be invalid. Other cases have inroked the doctrines of undue breadth or vagueness, which are mixed concepts of procedural and substantive due process, to strike down similar legislation. ${ }^{15}$ In Aptheker v. Secretary of State ${ }^{10}$ a federal statute denying passports to members of the Communist Party was held unconstitutional on the ground that it was not narrowly drafted to meet a specific evil. Yet the Court has never fully articulated the reasons for the difference in its approach to these two lines of cases.

The distinction is nevertheless a fundamental one. In the MeyerAptheker type of case, the legislation touches upon fundamental individual and personal rights essential to maintaining the independence, integrity, and private development of a citizen in a highly organized, yet democratic society. In the Lochner-Nebbia situation, the legislation deals with economic regulation of commercial and property rights, essential to maintaining the public interest in controlling a highly complex, industrialized society. The distinction is thus basic in striking the balance between public interest and private right in a modern, technologically developed nation.

The Connecticut birth control case would have been an opportune- one in which to clarify due process doctrine along the lines indicated. But the Court chose not to rest its decision on straight due process grounds and hence never reached these issues directly. However, there is language in the opinions which indicates that a majority of the Court are ready to apply the distinction. Mr. Justice Douglas stated in the prevailing opinion:

We do not sit as a super-legislature to determine the wisdom, need, and propriety of laws that touch economic problems, business affairs, or social conditions. This law, however, operates directly on an intimate relation of husband and wife and their physician's role in one aspect of that relation. ${ }^{17}$

Mr. Justice Goldberg, concurring for himself and Mr. Chief Justice Warren and Mr. Justice Brennan, was even more explicit:

In a long series of cases this Court has held that where fundamental personal liberties are involved, they may not be abridged by the States simply on a showing that a regulatory statute has some rational relationship to the effectuation of

15. See, e.g., Baggett v. Bullitt, 377 U.S. 360 (1964); NAACP v. Alabama ex rel. Flowers, 377 U.S. 288 (1964); Cramp v. Board of Public Instruction, 368 U.S. 278 (1961); Louisiana ex rel. Gremillion v. NAACP, 366 U.S. 293 (1961); Shelton v. Tucker, 864 U.S. 479 (1960).

16. 378 U.S. 500 (1964).

17. 381 U.S. at 482 . 
a proper state purpose. "Where there is a significant encroachment upon personal liberty, the State may prevail only upon showing a subordinating interest which is compelling," Bates v. Little Rock, 361 U.S. 516, 524. The law must be shown "necessary, and not merely rationally related, to the accomplishment of a permissible state policy." McLaughlin $v$. Florida, 379 U.S. 184, 196.18

Mr. Justice White, alone among the majority, placed his decision squarely upon substantive due process grounds. The opinion is a narrow one, however, taking advantage of a concession made by counsel for Connecticut at oral argument that the sole purpose of the law was to prevent "promiscuous or illicit sexual relationships." Mr. Justice White did not have much trouble demolishing this position, and hence did not find it necessary to enter into more subtle analysis of the due process clause.

Mr. Justice Black and Mr. Justice Stewart did face the issue, however, and explicitly repudiated any distinction between the two types of due process cases. In fact, both Justices went farther, arguing that substantive due process should be limited to the issue of whether the legislation was unduly vague. ${ }^{19}$ The majority, it is clear, did not hold either view. It can be expected, therefore, that at some future time the distinction between personal rights and economic rights in the application of due process doctrine will be more fully elaborated.

\section{B. Substantive Due Process and Its Relation to Public Morals}

The second significant aspect of substantive due process arose out of the fact that the primary objective of the Connecticut statute, as far as could be determined, was to promote public morality by prohibiting the use of extrinsic devices to prevent conception, even within the marital relation. ${ }^{20}$ The enactment was, in other words, designed to compel adherence to a purely moral principle. Thus, to attack such legislation on due process grounds posed a special problem.

When legislation is designed to promote health, safety, or the

18. Id. at 497. It should be noted that Mr. Justice Goldberg was applying first amendment and racial-equal protection doctrine to issues of substantive due process.

19. Id. at 511-18, 520-24, 528 .

20. As noted above, counsel for Connecticut apparently abandoned this position at the oral argument, and Justices White and Goldberg relied upon this concession. Nevertheless, this seems to be the position taken by the Connecticut courts. See State v. Nelson, 126 Conn. 412, 424, 11 A.2d 856, 861 (1940). 
general welfare in a material sense, its validity under the due process clause can be tested by considerations that can be objectively determined and rationally weighed. The questions whether the statute is arbitrary or capricious, or has a reasonable relation to a proper legislative purpose, turn in such cases upon factual material which can be discovered and presented to the court and upon value judgments which are subject to exposition and debate. The Brandeis brief is, of course, a classic illustration of this approach to the due process clause.

When the legislation is designed to promote public morality, however, the problem of applying the standards of due process may take a different form. In some cases, such as a statute prohibiting prostitution, the moral purposes may be justified by reference to objective and rational factors relevant to the promotion of the general welfare. However, in other cases the legislature may undertake to legislate purely on the basis of moral principles which are not subject to objective evaluation. In such a case, how are the customary criteria of due process to be applied?

Justices Black and Stewart, as indicated above, would not attempt to apply substantive due process standards, other than vagueness, at all. But the other Justices repudiate this approach. Hence they cannot take the position that the simple claim of a moral aim by the legislature satisfies the requirement of due process. Any such a doctrine would immunize virtually all legislation from the mandate of the due process clause. It would allow the legislatures to impose restraints upon individual liberties solely on the ground that some insignificant fraction of the community regarded the issue as a moral one. Yet a law prohibiting women from appearing in public without veils or forbidding women to use lipstick or cosmetics, even though some persons in the community might regard such practices as immoral, would surely be held an arbitrary infringement of personal liberty outlawed by the due process clause. What, then, should be the constitutional standards for applying the due process clause in cases where the legislature seeks to promote public morals?

Counsel for appellants argued that the standard in such cases should at least be that (1) the moral practices regulated by the statute must be objectively related to the public welfare, or (2) in the event no such relationship can be demonstrated, the regulation must conform to the predominant view of morality in the community. In other words, if the legislature cannot establish that the law promotes the public welfare in a material sense, it cannot 
enforce the morality of a minority group upon other members of the community. The obscenity cases were cited as supporting a somewhat similar doctrine. It was further suggested that the first standard set forth above would be sufficient in itself, without the second. That is, if the moral principles cannot be objectively related to the public welfare, the legislation fails, for that reason alone, to meet the standards of due process. However, it was pointed out that it was not necessary to take this position in order to decide the case then before the Court.

Mr. Justice Stewart, although not meeting this argument squarely, apparently considered and rejected it. ${ }^{21}$ The other Justices did not refer to it. Obviously the problem raises crucial but controversial questions respecting the relation of law and morals. The Court was not willing to venture into such a delicate area. Perhaps one cannot blame them.

\section{NINTH AMENDMENT}

The ninth amendment issue was not raised at the trial by the appellants, and was urged in the Supreme Court only as one source of the right of privacy. However, to the astonishment of many observers, five of the Justices accepted the invitation to consider the ninth amendment as a basis for invalidating the Connecticut statute. Mr. Justice Douglas invoked it as one of the constitutional guarantees from which the right of privacy was derived. Mr. Justice Goldberg discussed it at length, but his opinion seems to give it a more limited significance. He expressly repudiated the argument that the ninth amendment "constitutes an independent source of rights protected from infringement by either the States or the Federal Government."22 Rather, his position was that "the Ninth Amendment shows a belief of the Constitution's authors that fundamental rights exist that are not expressly enumerated in the first eight amendments and an intent that the list of rights included there not be deemed exhaustive."23 The specific rights must therefore still be derived from other sources.

The fact that a majority of the Supreme Court, for the first time, relied upon the ninth amendment in any serious way to strike down state legislation is an event of considerable importance. Yet there remains grave doubt that the ninth amendment has a significant future. Mr. Justice Goldberg's formulation does not seem to open

21. 381 U.S. at 530.

22. Id. at 492 .

23. Ibid. 
any really new possibilities. The doctrine that the due process clause protects certain fundamental rights not expressly mentioned in the Bill of Rights or elsewhere in the Constitution is well established, and has been utilized on many other occasions. ${ }^{24} \mathrm{Mr}$. Justice Douglas' use of the ninth amendment carries a greater potential. Under his theory, the ninth amendment might be utilized to expand the concept of privacy or, perhaps, to guarantee other basic rights. It would hardly be surprising, however, if this development were some decades away.

\section{The Right of Privacy}

Since no constitutional "right of privacy" had previously been recognized, at-least as an independent doctrine, in order to dispose of the case on this ground it was necessary to establish a new constitutional concept. This involved three major problems. One was to determine the source from which the new doctrine was derived, a second was to indicate the standards by which the doctrine would be applied, and the third was to suggest, if only tentatively, the scope of its application.

\section{A. The Creation of the Right}

With respect to the initial problem of determining the source of the right of privacy, there were two approaches available. The first was to argue that, although the Constitution nowhere refers in express terms to a right of privacy, nevertheless various provisions of the Constitution embody separate aspects of such a concept, and the composite of these protections should be accorded the status of a recognized constitutional right. This approach was adopted in the prevailing opinion of Mr. Justice Douglas: "Specific guarantees in the Bill of Rights have penumbras, formed by emanations from those guarantees that help give them life and substance."25 From the first amendment, the third amendment, the fourth amendment, the privilege against self-incrimination of the fifth amendment, and the ninth amendment, he concluded that "the right of privacy which presses for recognition here is a legitimate one." 20

The second approach starts from the position that the due process clause of the fourteenth amendment, whether or not it incorporates some or all of the provisions of the Bill of Rights, guarantees

24. Mr. Justice Goldberg himself cites, among other cases, Aptheker v. Secretary of State, 378 U.S. 500 (1964), and Bolling v. Sharpe, 347 U.S. 497 (1954).

25. 381 U.S. at 484.

26. Id. at 485 . 
such basic rights as are "implicit in the concept of ordered liberty." The right of privacy can be considered such a fundamental right and hence protected under the due process clause. This view of the matter was taken by Mr. Justice Harlan in his concurring opinion. ${ }^{27}$

Mr. Justice Goldberg, in his opinion joined by the Chief Justice and Mr. Justice Brennan, seems to have combined both approaches. He expressly accepted Mr. Justice Douglas' view that a right of privacy was "protected, as being within the protected penumbra of specific guarantees of the Bill of Rights."28 However, he also pointed out that "the concept of liberty protects those personal rights that are fundamental, and is not confined to the specific terms of the Bill of Rights." $29 \mathrm{He}$, too, went on to find that the right of privacy was a fundamental right.

The precise source of the right of privacy is not as important as the fact that six Justices found such a right to exist, and thereby established it for the first time as an independent constitutional right. It was a bold innovation. Yet it was not entirely without precedent. The Court had previously recognized a somewhat similar "right of association" derived from the various specific guarantees of freedom of speech, press, assembly, and petition in the first amendment. ${ }^{30}$

In any event, the creation of a right to privacy is a step with enormous consequences. The concept of limited government has always included the idea that governmental powers stop short of certain intrusions into the personal life of the citizen. This is indeed one of the basic distinctions between absolute and limited government. Ultimate and pervasive control of the individual, in all aspects of his life, is the hallmark of the absolute state. In contrast, a system of limited government safeguards a private sector, which belongs to the individual, firmly distinguishing it from the public sector, which the state can control. Protection of this private sector-protection, in other words, of the dignity and integrity of the individual - has become increasingly important as modern society has developed. All the forces of a technological age-industrialization, urbanization, and organization-operate to narrow the area of privacy and facilitate intrusions into it. In modern terms, the capacity to maintain and support this enclave of private life marks the difference between a democratic and a totalitarian society.

27. Id. at 500. Mr. Justice Harlan's views are stated at greater length in his dissenting opinion at a prior stage of the litigation. See Poe v. Ullman, 367 U.S. 497, 522 (1961).

28. 381 U.S. at 487.

29. Id. at 486 .

30. See the line of cases beginning with NAACP v. Alabama ex rel. Patterson, 357 U.S. 449 (1958), collected in Emerson, supra note 7, at 6-15. 


\section{B. Standards of Application}

Having established the constitutional right of privacy, the Court was confronted with the second problem-determination of the standards by which the new doctrine would be applied. Mr. Justice Douglas dealt with this question somewhat summarily. He noted that the Connecticut law, "in forbidding the use of contraceptives rather than regulating their manufacture or sale, seeks to achieve its goals by means having a maximum destructive impact upon [the marriage] relationship." 31 He mentioned specifically the problem of actual enforcement, of allowing the police "to search the sacred precincts of marital bedrooms for telltale signs of the use of contraceptives." $32 \mathrm{He}$ also applied the rule against undue breadth: "Such a law cannot stand in light of the familiar principle, so often applied by this Court, that a 'governmental purpose to control or prevent activities constitutionally subject to state regulation may not be achieved by means which sweep unnecessarily broadly and thereby invade the area of protected freedoms.' "33

The Goldberg opinion proceeded in a somewhat different direction. It took as its primary standard a balancing test, but one which placed a heavy burden of justification upon the government: "[T]he State may prevail only upon showing a subordinating interest which is compelling." ${ }^{4} \mathrm{Mr}$. Justice Goldberg also reiterated the Douglas position that the law must not "sweep unnecessarily broadly," and added that other Connecticut laws on adultery and fornication "demonstrate that means for achieving the same basic purpose of protecting marital fidelity are available to Connecticut without the need to 'invade the area of protected freedoms.' "35

While the Court is thus not settled upon the exact formula by which to determine whether the right of privacy has been infringed, it would seem clear that the test is more severe than that applied in substantive due process cases involving economic regulation. On the other hand, in view of the newness of the constitutional right, the vagueness of the concept, and the general lack of precise standards, it would appear that there is little prospect of working out any such strict test as has been proposed for first amendment cases. It is most likely that future decisions will follow the Goldberg ap-

31. 381 U.S. at 485.

32. Ibid.

33. Ibid. Mr. Justice Douglas had previously elaborated his vicws in Poc v. Ullman, 367 U.S. 497 (1961), where he had also stressed primarily the impact of enforcement activities upon marital privacy.

34. 381 U.S. at 497.

35. Id. at $497-98$. 
proach-a balancing of factors, with the government required to show a "compelling interest," supplemented by doctrines of undue breadth, vagueness, and the feasibility of alternative measures.

\section{The Scope of the Right}

With respect to the third problem-the scope of the right of privacy-the Court proceeded with its customary caution when venturing into new fields. The facts of the case before it, although strong, embraced a relatively narrow area. They were confined to a use statute, discriminatory in operation, which had been applied to married couples. The Douglas opinion, to the extent it deals specifically with the scope of the right to privacy, treats only of the "marriage relationship." The Goldberg opinion is also addressed to the "right of marital privacy," although it does refer to the privacy of "the marital home" and the right "to marry and raise a family." It is conceivable that in future cases the Court will limit the doctrine to the marriage relationship, or even refuse to extend it beyond the precise facts of the Connecticut case. However, such an outcome seems unlikely, since constitutional doctrines have a way of expanding beyond the boundaries of the original case. This is especially true where, as here, the right established is one which responds so acutely to the growing needs of the society. It is impossible to foretell, of course, what the future course of development may be. But it is not hard to anticipate some of the claims that will be pressed upon the Court in the coming years. And any appraisal of the significance of the Court's action in the Connecticut case demands some speculation, however brief and uncertain, concerning the Court's response.

One series of issues revolves around the same aspect of the right to privacy as that involved in Griswold-the marital relationship. It would seem reasonably clear that other laws attempting to prohibit certain kinds of sexual activity by married couples, such as so-called acts of "perversion," requiring a type of enforcement similar to that implicit in the Connecticut statute, would fall under the ban against invasion of privacy. Less clear, however, is the fate of state laws regulating not the use of contraceptive devices, but their manufacture, sale, or distribution. Plainly, many forms of regulationsuch as those designed to safeguard health or safety, or requiring distribution through physicians or licensed drug stores-would be upheld. But would an attempt by the state to enforce a total prohibition of access to contraceptives by married couples, such as the 
Massachusetts statute, ${ }^{36}$ constitute an invasion of the right of marital privacy? In this situation, the nature of the right is not coterminous with that protected in the Griswold case. It no longer involves those aspects of police enforcement which loomed so large under the Connecticut statute. Rather it consists primarily in the right to have or not have children, and to plan a family. In view of $\mathrm{Mr}$. Justice Goldberg's inclusion of the "right to marry and raise a family" within the right of privacy, and in view of the fundamental nature of such a right, it would not be surprising if the Court accepted such a claim.

If this supposition is accurate, then the corollary would seem to follow that action by the government to compel limitation of births, at least in the absence of special compelling circumstances, would also constitute an invasion of privacy. Indeed, Mr. Justice Goldberg stated this as an a fortiori proposition. The new doctrine thus carries serious implications for sterilization laws and future birth control programs. Undoubtedly the government could encourage birth control by many means other than strict compulsion, but a line between encouragement and coercion would have to be worked out. On the same view of the scope of the right to privacy, the way would be open for an attack upon significant aspects of the abortion laws.

An additional area in which claims to the right of privacy are likely to be invoked embraces the multitude of existing laws relating to sexual conduct outside the marital relation. It seems unlikely that the Court would disturb most of the legislation relating to adultery, fornication (commercial or otherwise), and homosexuality. Indeed, Justices Goldberg and Harlan expressly disclaimed any such intention. However, some of the particularly arbitrary, irrational, or unenforceable aspects of such legislation might be vulnerable. It is conceivable that sometime in the future, as mores change and knowledge of the problem grows, all sexual activities of two consenting adults in private will be brought within the right of privacy.

Apart from sex laws, it would not be surprising to see the concept of privacy employed in a number of other situations to safeguard the private sector of our lives from government encroachment. One obvious area in which this concept is sure to be pressed and may well be successful, at least in part, is electronic eavesdropping. The scientific possibilities are so fantastic and the invasion of privacy

36. MASs. GEN. LAws ch. 272, § 21 (1932). 
so devastating that it is hard to believe a civilized society will not feel compelled to throw up some protection to individuals. This may come about through legislation, but the constitutional right of privacy could also play a significant role. ${ }^{37}$

Other such areas also come to mind. Various kinds of police practices, not technically covered by the search and seizure guarantees of the fourth amendment, would easily fall within an expanding concept of the right to privacy. ${ }^{38}$ Efforts by government officials to compel the production of private information through legislative committees, lie-detector tests, or other similar means may gradually be brought within the constitutional doctrine. Release of official records of arrests not resulting in conviction might be curtailed. Finally, the whole field of social welfare legislation and administration may be forced into procedures and practices more compatible with human dignity and integrity. Thus, restrictions imposed by official or semi-official welfare agencies upon the private life or activities of welfare recipients may well become subject to the new guarantees of privacy. ${ }^{38}$

The foregoing observations are merely-indicative of some of the areas that may be encompassed within an expanded concept of the right to privacy. Undoubtedly the Court will proceed slowly, developing the right to privacy on a case-by-case basis. The essential point is that the key constitutional doctrine has been enunciated, and many forces in our society will press hard toward fuller realization of its great potential.

\section{Conclusion}

What, then, are we to conclude about the Court's performance in the birth control case? On the whole, the Court's choice of the privacy doctrine as the basis of its decision seems sound. Unprecedented as it was, and as broad and ill-defined as it remains, the doctrine still represents the narrowest and most precise formula available, and the one most relevant to the issues presented. This

37. See, e.g., Judge Washington's dissent in Silverman v. United States, 275 F.2d 173, 178 (D.C. Cir. 1960).

38. It should be noted that to the extent specific activities of government officials are held to violate the constitutional right of privacy, they may be subject to criminal prosecution and civil redress under federal civil rights legislation. See, e.g., York v. Story, 324 F.2d 450 (9th Cir. 1963), holding that allegations that police officers took photographs of a woman complainant in the nude and distributed them among their fellow officers stated a cause of action under REv. STAT. \$1979 (1875), 42 U.S.C. \& 1983 (1964).

39. See Reich, Individual Rights and Social Welfare-The Emerging Legal Issues, 74 YALE L.J. 1245 (1965). 
creation of a new constitutional protection meets a critical need of society, and the new doctrine seems to have a viable and significant future.

The Court will undoubtedly be attacked upon the broader ground that, since the objections to the Connecticut law did not fall clearly within any established and specific legal category, the Court should not have invalidated the law at all. Supporters of the argument for "neutral principles" can hardly be satisfied that the creation of a new principle conforms to their view of the Court's function. Furthermore, the concern of Mr. Justice Black, forcefully expressed in his dissent, that more is to be gained by strict adherence to specific provisions of the Constitution than by excursions into the realm of "natural law," cannot be discarded lightly. Yet it is significant that Mr. Justice Harlan, the most ardent advocate of judicial self-restraint now on the Court, joined in the establishment of the new constitutional right to privacy. This indicates that, in the context of the case before it, the claim to constitutional protection presented could not readily be thrust aside. In any event, the role of the Court as guardian of individual rights has been both solidified and advanced. 